\title{
HARMONISASI WORK FROM HOME PADA MODEL PENGEMBANGAN KARIER WANITA
}

\section{Yeyen Komalasari}

Article history:

Submitted:

22 Februari 2022

Revised:

27 Februari 2022

Accepted:

27 Februari 2022

\section{Keywords:}

Covid-19;

Work From Home;

Career Development;

Women,S Career;

Career Cycle.

\section{Kata Kunci:}

Covid-19;

Work From Home;

Pengembangan Karier;

Wanita Karier;

Siklus Karir.

\section{Koresponding:}

Universitas Dhyana Pura, Bali, Indonesia

Email:

yeyenkomalasari@undhirabali.a c.id

\section{Abstract}

This study aims to reveal and understand in depth about how women carry out company policies to enforce work from home (WFH) rules in their career development models. The researcher uses the interpretive paradigm and phenomenology as a basis to obtain a comprehensive description of individual speech and behavior, so as to be able to know the harmonization of Work From Home at the stages of the women career development cycle. The key informants in the study were 6 career women who were in the early, mid to late career phases. The results show that in the idealistic achievement model phase, WFH for women is seen as an obstacle in achieving their careers; the pragmatic endurance model phase, WFH makes life easier for them to carry out their dual roles in a balanced way; In the re-inventive contribution model phase, WFH has a fun impact, because they can work from home while pursuing a hobby so they are happier.

\begin{tabular}{l} 
Abstrak \\
\hline \\
Penelitian ini bertujuan mengungkap dan memahami secara mendalam \\
tentang bagaimana wanita menjalankan kebijakan perusahaan \\
pemberlakuan aturan bekerja dari rumah (Work From Home /WFH) dalam \\
model pengembangan kariernya. Peneliti menggunakan paradigma \\
interpretif dan fenomenologi sebagai pijakan untuk memperoleh sebuah \\
deskripsi tentang ucapan dan perilaku individu secara komprehensif, \\
sehingga mampu mengetahui harmonisasi Work From Home pada tahapan \\
siklus pengembangan karier wanita. Informan kunci dalam penelitian \\
adalah 6 orang wanita karier yang berada dalam fase awal, pertengahan \\
hingga akhir karier. Hasil penelitian menunjukkan bahwa pada fase \\
idealistic achievement model, WFH bagi wanita dipandang sebagai \\
hambatan dalam mencapai karier mereka; fase pragmatic endurance model, \\
WFH membuat hidup mereka lebih mudah untuk menjalani peran gandanya \\
dengan seimbang; fase re-inventive contribution model, WFH berdampak \\
menyenangkan, karena mereka dapat bekerja dari rumah sambil \\
menjalankan hobi sehingga lebih bahagia.
\end{tabular}




\section{PENDAHULUAN}

Pandemi COVID-19 melanda seluruh dunia dan merupakan tantangan besar bagi perusahaan baik yang bergerak di sector pemerintahan maupun swasta. Meminimalkan kontak erat adalah salah satu upaya untuk memutus penyebaran virus, yang disebut physical distancing (Pfattheicher et al., 2020). Membatasi jarak fisik merupakan langkah untuk melindungi diri dan orang lain. Pembatasan physical distancing lebih tepat dibandingkan social distancing, karena yang kita batasi adalah jarak fisik sedangkan sosialisasi, solidaritas, tanggung jawab, serta kerja sama harus di tingkatkan menghadapi pandemi ini (Kumar, 2020). Dibanyak negara termasuk Kota Wuhan, Cina menutup berbagai industri tempat usaha dan sekolah guna mencegah penyebaran pandemi (Prem et al., 2020). Indonesia juga melakukan hal yang serupa, melalui arahan Presiden Joko widodo tentang penanganan COVID_19 di Istana Bogor, Minggu 15 Matret 2020, pemerintah secara resmi menghimbau masyarakat untuk mengurangi aktivitas dengan melakukan kegiatan bekerja, belajar dan beribadah di rumah. Berdasarkan arahan tersebut, maka per tanggal 16 Maret 2020, beberapa perusahaan baik pemerintah maupun swasta mulai menerapkan himbauan bekerja dari rumah (Work From Home/WFH). Work Form Home merupakan strategi tindakan pencegahan yang bertujuan untuk mengurangi penularan masyarakat demi mengalahkan pandemic, hal ini mengubah gaya hidup karyawan (Raju \& Kumar, 2020). WFH merupakan istilah bagi karyawan yang melakukan pekerjaannya dari rumah. Karyawan tidak bekerja secara fisik datang ke kantor dan bertemu dengan sesama karyawan lainnya. Biasanya perusahaan mengatur karyawan secara bergantian, siapa yang bekerja di kantor (offline) dan siapa yang bekerja dari rumah (online). Dari hasil penelitian dikatakan bahwa frekuensi WFH sangat penting, yakni semakin sering karyawan bekerja dari rumah, maka semakin tinggi upaya kerja yang mereka berikan terutama bagi karyawan wanita (Rupietta \& Beckmann, 2018).

WFH merupakan angin segar bagi karyawan wanita yang memiliki peran ganda, dimana mereka berpendapat bahwa dengan bekerja dari rumah akan memiliki waktu yang lebih fleksibel, sehingga dapat menyeimbangkan perannya. WFH bagi karyawan wanita merupakan tempat berjuang untuk menyeimbangkan, memperluas serta memodifikasi pemenuhan fungsi dan perannya dalam rumah tangga, pekerjaan dan bidang social (Elfira et al., 2021). Hal ini sejalan dengan penelitian yang dilakukan oleh (Raju \& Kumar, 2020) mereka mengatakan bahwa faktor lingkungan bekerja dari rumah ditemukan signifikan berhubungan dengan kualitas hidup yang lebih baik bagi mayoritas pekerja wanita. Situasi Lockdown membuat perempuan lebih aktif, mobile dan dapat menyeimbangkan antara pekerjaan dan keluarga pada 67,3 persen responden sudah menikah dan bekerja dari rumah dan 48 persen responden mengatakan bahwa WFH berdampak pada gaya hidup karyawan dengan mampu mempertahankan kualitas hidup 
mereka yang lebih baik seperti kesehatan fisik, kesehatan psikologis, social.

Pendapat berbeda diungkapkan oleh van der Lippe \& Lippényi (2020), mereka menemukan bahwa WFH sekarang telah menjadi budaya dalam kehidupan kerja modern. Meskipun banyak yang mengemukakan berbagai solusi untuk menggabungkan pekerjaan dengan kehidupan keluarga, namun secara mengejutkan hanya sedikit bukti empiris yang mendukung bahwa hal itu mengurangi konflik pekerjaankeluarga. Survei Tenaga Kerja Eropa yang dilakukan di 259 organisasi, 869 tim, dan 11.011 karyawan di sembilan negara (Bulgaria, Finlandia, Jerman, Hongaria, Belanda, Portugal, Spanyol, Swedia, Inggris Raya), menunjukkan bahwa budaya pekerja yang ideal memperkuat peningkatan konflik pekerjaan-keluarga karena bekerja dari rumah dan wanita cenderung lebih sensitif terhadap proporsi rekan kerja yang bekerja dari rumah, sehingga dapat dikatakan bahwa WFH sangat berdampak pada para pekerja wanita dibandingkan pria. Penelitian senada dari 100 wanita yang bekerja pada 25 bank di India belum memanfaatkan WFH untuk menyeimbangkan kehidupan pribadi dan profesional. Budaya kerja lama yang belum ditinggalkan justru meningkatkan konflik pekerjaan dan keluarga karena pilihan bekerja dari rumah (Kaur \& Sharma, 2020).

Dari penelitian sebelumnya terdapat berbagai pendapat yang menyatakan prokontra tentang WFH bagi pekerja wanita, ada yang mengatakan WFH merupakan dambaan bagi wanita karena mampu menyeimbangkan perannya sehingga menimbulkan kualitas hidup yang lebih baik kesehatan fisik, kesehatan psikologis, social. Disisi lain ada pula yang mengatakan bahwa WFH justru menimbulkan konflik pekerjaan-keluarga dan wanita yang paling sensitif terdampak. Berdasarkan hal tersebut ada sebuah kesamaan bahwa WFH sangat berdampak pada pekerja wanita, namun celah yang belum terjawab bahwa bisa saja perbedaaan pandangan tersebut dikarenakan, belum dilakukan penelitian mendalam mengenai pendapat pekerja wanita pada berbagai kelompok usia disiklus karier mereka. WFH dapat membawa pengaruh yang berbeda pada masing-masing usia pekerja wanita ditahapan atau siklus pengembangan kariernya.

Model pengembangan karier bagi wanita dapat dilihat dari tahap kehidupan pekerja wanita, yang menekankan pentingnya memperhatikan bagaimana cara wanita menjalani kehidupan kerja sesuai dengan usianya. (Komalasari, Supartha, 2017). Model ini berawal dari pemahaman bahwa karyawan wanita merancang sendiri pola karier mereka, karena wanita memandang kariernya secara subyektif berdasarkan tahapan siklus kehidupannya. Model pengembangan karier wanita dapat dibagi menjadi tiga tahapan berdasarkan peningkatan usia mereka yaitu: idealistic achievement model tahap awal karier usia 24-34 tahun, pragmatic endurance model tahap pertengahan karier usia 36-45 tahun dan re-inventive contribution model tahap akhir karier usia 4660 tahun (O’Neil \& Bilimoria, 2005; Komalasari, 2020).

Berdasarkan rumusan masalah yang telah dikemukakan tersebut, maka tujuan 
penelitian ini adalah: untuk memahami harmonisasi dampak work from home pada tiga tahapan/siklus kehidupan karier pekerja wanita di wilayah Denpasar berdasarkan model pengembangan karier wanita. Hal ini akan dapat membantu wanita karier dalam mengambil keputusan karier dalam hidupnya, dan mampu memberikan informasi kepada pihak perusahaaan untuk mengambil kebijakan terhadap wanita karier.

\section{METODE PENELITIAN}

Penelitian ini dilakukan pada wanita karier karena berbagai penelitian sebelumnya mengatakan bahwa WFH paling berdampak pada wanita (van der Lippe \& Lippényi, 2020; Raju \& Kumar, 2020; Kaur \& Sharma, 2020; Banerjee \& Pati, 2020). Wanita yang berdomisili di wilayah Denpasar dipilih, karena Denpasar merupakan pusat pemerintahan dan bisnis di Bali, sehingga tekanan pekerjaan dan tuntutan peran yang dimiliki lebih kompleks. Jenis penelitian ini merupakan penelitian kualitatif yang bertujuan untuk memahami fenomena yang dialami oleh partisipan secara menyeluruh dalam bentuk kata-kata dan bahasa pada konteks dan metode alamiah (Moleong, 2019). Penelitian ini merupakan penelitian kualitatif yang menggunakan pendekatan fenomenologi interpretatif secara kritis menggali fenomena dari pengalaman responden secara sistematis untuk mengembangkan sebuah pemaknaan. Penelitian ini mengamati berbagai perubahan baik pemikiran maupun perilaku wanita karier sesuai dengan tahapan usia kehidupannya.

$$
\text { Partisipan sebagai informan }
$$
penelitian merupakan unit analisis individu yang dipilih dengan tujuan mendapatkan segala informasi pengalaman sesuai fokus penelitian terkait WFH dalam kehidupan karier wanita. Teknik nonprobability sampling melalui purposive sampling atau penentuan partisipan yang dipilih dengan kriteria atau dasar pertimbangan dan tujuan tertentu (Sugiyono, 2016). Kriteria yang dimaksud dalam penelitian ini adalah wanita bekerja di wilayah Denpasar baik di instasi pemerintah maupun swasta., bekerja dari rumah $(W F H)$, sudah menikah dan memiliki anak. Responden dalam penelitian ini berjumlah 6 orang. Adapun data responden dalam penelitian ini pada Tabel 1 .

Tabel 1.

Data Responden

\begin{tabular}{lcllc}
\hline Tahap Karier & $\begin{array}{c}\text { Umur } \\
\text { (th) }\end{array}$ & \multicolumn{1}{c}{ Tempat Bekerja } & \multicolumn{1}{c}{ Nama } & Kode \\
\hline Awal & 33 & Kanwil Kementrian Agama Prov. Bali & Tia Sastrina ST,MM & TS \\
\cline { 2 - 5 } $24-35$ th & 34 & PT. Artha Bali Computindo & Ni Kadek Eny Hartayani, SE. & EH \\
\hline Tengah & 37 & PT. BPJS Provinsi Bali & $\begin{array}{l}\text { Ni Putu Widya Santhi Dewi } \\
\text { Nugraheni }\end{array}$ & SD \\
36-45 th & 41 & PT. Galang Bangun Luhur Property & Agung Dewi Saraswati, SE. & DS \\
\hline Akhir & 51 & PT. Bank Negara Indonesia tbk & Luh Sri Wahyni, SE., Ak. & SR \\
46-60 th & 53 & Rumah Sakit Jiwa Prov. Bali & Kadek Ayu S.E., MM. & KA \\
\hline
\end{tabular}

Sumber: diolah, 2021 
Human instrument digunakan dalam penelitian ini, yaitu peneliti itu sendiri yang sebelumnya sudah melakukan proses validasi mengenai kesiapan dan pemahaman terhadap metode, teori dan wawasan pada bidang yang akan diteliti dan kemudian terjun ke lapangan melakukan penelitian. Peneliti menetapkan fokus penelitian, memilih informan sebagai partisipan, mengumpulkan data, menilai kualitas data, menganalisis data, menafsirkan data, dan terakhir membuat kesimpulan (Poerwandari, 2011).

Data dikumpulkan melalui in depth interview, guna mencari sesuatu pemaknaan yang mendalam. Kemudian data tersebut dianalisis melalui IPA (Interpretative Phenomenological Analysis) (Smith \& Osborn, 2008). Dengan tahapan sebagai berikut. Pertama, Reading and re-reading. Peneliti membuat, membaca kemudian menuliskan transkrip wawancara. Setiap kata-kata dan kalimat dari partisipan hasil wawancara perlu dibaca kembali secara berulang oleh peneliti dalam membantu analisis data yang lebih komprehensif pada fase analisis; Kedua, Initial noting. Peneliti melakukan pengujian pada setiap isi dari kata-kata, kalimat dan bahasa yang diungkapkan partisipan serta mencatat segala sesuatu yang dianggap menarik pada transkrip. Disini peneliti akan menemukan catatan-catatan interpretatif yang mampu menggambarkan pengalaman wanita karier dalam pelaksanaan $\mathrm{WFH}$, kemudian memberi pemaknaannya terhadap pengembangan kariernya; Ketiga, Developing emergent themes. Peneliti menemukan munculnya pengembangan tema-tema tertentu, dari catatan-catatan pada tahapan sebelumnya. Lalu menganalisis tanggapan wawancara tersebut, sehingga transkrip kemudian menjadi jelas;

\section{Keempat, Searching for connection} a cross emergent themes. Makna antara tema yang satu dengan tema yang lainnya dikembangkan dan saling dihubungkan kemudian dipetakan serta diurutkan secara kronologis; Kelima, Moving the next cases. Tahap analisis pertama sampai keempat dilakukan pada setiap partisipan secara berulang, apabila satu kasus selesai dianalisis, maka akan pindah kepada partisipan berikutnya, sampai semua kasus partisipan tuntas; Keenam, Looking for patterns across cases. Peneliti memperluas sudut pandang dan pemaknaaan pengalaman dari setiap partisipan. Peneliti mencari pola-pola antar kasus dari partisipan, kemudian menghubungkannya. Membandingkan pemaknaan antar satu partisipan dengan partisipan lain dapat memperluas interpretasi penelitian.

Setelah keenam tahapan tersebut kemudian dilakukan member check, yaitu proses pengecekan data-data yang diperoleh peneliti pada partisipan dengan tujuan pemantapan kredibilitas data penelitian, sesuai sumber data atau partisipan. Data tersebut bisa dinyatakan valid dan kredibel jika disepakati oleh partisipan, namun apabila data dengan berbagai pemaknaaan dan interpretasi dari peneliti tidak disepakati oleh partisipan, maka temuan harus diubah kembali sampai terjadi kesepakatan (Sugiyono, 2016). 


\section{HASIL DAN PEMBAHASAN}

Hasil wawancara mendalam (in depth interview) menggambarkan perilaku work from home (WFH), berdasarkan model pengembangan karier wanita, pada 6 orang partisipan sebagai berikut. Informasi Partisipan 1, inisial TS, Pegawai Negeri Sipil, Usia 33 Tahun. Menyenangi tugas yang menantang, tanggung jawab tinggi, untuk membuktikan kemampuan dirinya dengan harapan keberhasilan pekerjaan yang diraih tersebut, menjadi indikator penilaian kenaikan jabatan seperti yang berlaku selama ini diperusahaannya. TS seringkali dipercaya untuk mengemban tugas mewakili kantor dalam berbagai kesempatan, dengan ide-ide baru yang terbukti membawa Kementrian Agama Provinsi Bali kerap kali mendapatkan penghargaan dari pusat. Namun dengan adanya WFH, TS tidak bisa fokus bekerja di rumah, pekerjaan menjadi tidak maksimal, karena di rumah seringkali konsentrasi bekerjanya teralihkan, sambil menjaga dan mengurus 3 anaknya yang masih berumur 3 th, 5 th dan 7 th untuk makan, bermain dan juga belajar online.

Informasi Partisipan 2, inisial $\mathrm{EH}$, Karyawan Swasta, Usia 34 Tahun. Ibu tiga anak ini sangat bersemangat apabila diberikan kesempatan untuk mengetuai sebuah project, menyiapkan dan memamparkan presentasi di depan orang banyak, mengusulkan ide dan gagasan baru, sehingga memang senang dan ingin terlihat lebih menonjol dibandingkan yang lain. Kemampuan dan prestasi yang ditunjukkan sangat bagus dan performa tersebut seringkali mendapat apresiasi, baik dari pimpinan sebagai atasan maupun teman sejawat dan juga bawahan di tempatnya bekerja. Dukungan yang diperoleh ini membuatnya semakin mantap untuk naik jabatan, meningkatkan jenjang kariernya ke hirarki yang lebih tinggi. Dampak WFH terhadap pekerjaannya adalah EH seringkali kehilangan ide saat bekerja di rumah, ketika ide datang seringkali lenyap karena tiba-tiba anak-anak bertengkar, menangis, maupun rewel meminta sesuatu. Hal ini seringkali meninmbulkan stress dan keputusasaan dalam mengerjakan project. EH memiliki 3 orang anak berumur 6 th, 8 th dan 12 th.

Informasi Partisipan 3, inisial SD, seorang Pegawai Negeri Sipil. Usia 37 tahun. Menikah dan memiliki 3 anak. SD dalam kehidupan pekerjaanya lebih memilih tidak berada pada barisan terdepan atau memilih posisi yang tidak terlihat, artinya walaupun dia mengerjakan tugasnya dengan baik, namun tidak ingin menonjol dibandingkan rekan kerja yang lain, karena takut apabila terlihat terlalu pintar bekerja atau berprestasi, maka dia akan dianggap mampu untuk memimpin, sehingga berpotensi untuk diberikan tugas dan tanggung jawab yang lebih besar dan dipindahkan di cabang perusahaan yang berada di kota lain, jauh dari keluarga. Jika hal ini terjadi maka tanggung jawabnya pada keluarga akan terbengkalai, terlebih lagi anaknya masih kecil-kecil dan belum mandiri. Anak ketiganya masih PG (Play Group) dan dua anak yang lainnya masih Sekolah Dasar, disamping itu juga SD hanya memiliki asisten rumah tangga yang bekerja setengah hari, hal ini tentu menyulitkan dan sungguh membebani pikiran ketika harus pergi bertugas keluar kota, yang 
tentunya memakan waktu beberapa hari. Dengan adanya WFH, dampak yang paling dirisaukan selama ini yakni tugas luar kota, sudah tidak pernah ada lagi. Hal ini yang menyebabkan SD merasa nyaman dengan WFH, selain tentunya karena di rumah dapat lebih intens menjaga anak-anaknya.

Informasi Partisipan 4, inisial DS, seorang karyawan swasta, berusia 42 tahun. Sudah menikah dan memiliki 2 anak, keadaan ini membuatnya lebih berhati-hati menerima tawaran pekerjaan memimpin sebuah project apalagi pekerjaannya di property menuntut DS kerja lapangan seperti mengecek lahan dan mengurus legalitas bangunan. Kerja lapangan ini tidak memungkinkan dia melakukan WFH, karena harus langsung ke lokasi. Tidak seperti dulu sewaktu masih single, diawal karier DS begitu semangat memimpin project, karena fokus DS sekarang terbagi menjadi tanggung jawab keluarga dan profesional. DS lebih memilih menjadi anggota sebuah project daripada pimpinan, karena dengan demikian masih ada waktu dan kesempatan bagi DS untuk memikirkan keluarga dengan tugas dan tanggung jawab yang lebih ringan. Disela waktu kerja di rumah DS dapat membantu anak-anaknya untuk belajar dirumah mengerjakan tugas sekolah online, yang sekarang semakin rumit dan butuh pendampingan orang tua. Walaupun demikian seluruh tugas dan tanggung jawab profesional yang diberikan perusahaan kepadanya selalu diselesaikan dengan baik dan tepat waktu. Disini DS lebih memilih keseimbangan peran, tidak ngotot ingin terlihat unggul di pekerjaan tp lebih memilih untuk berdamai antara pekerjaan dan rumah tangga. Dampak WFH bagi kariernya justru membuat hidupnya lebih mudah, menjalani keduanya dengan santai, tanpa beban. Hal ini karena DS sengaja mengambil porsi pekerjaan yg lebih sedikit untuk menghindari tanggungjawab yang lebih besar, sehingga sekaligus dapat memantau anakanak dirumah, dimana anak-anaknya sudah menginjak remaja yaitu SMP dan SMU.

Informasi Partisipan 5, inisial SR. Pegawai Negeri Sipil. berusia 51 tahun. Memiliki 3 orang anak, yang sudah berusia remaja 2 orang (SMP dan SMA) dan dewasa 1 orang sedang menempuh pendidikan di Universitas Udayana. SR sekarang sudah menentukan sendiri pola kariernya menuju masa pensiun, lebih senang untuk menghabiskan sisa kariernya dengan membantu rekan kerja dan dapat memberi manfaat buat orang lain atau juniornya. Senang berbagi ilmu, sehingga banyak memiliki teman dan menjauh dari persaingan kerja. Ambisi untuk pengembangan karier tidak terpikirkan lagi dalam benaknya. Sekarang tujuannya hanya bekerja dengan baik dan melihat keluarga (anak-anak) berhasil dalam studi mereka. SR kini bekerja tanpa beban, ibaratnya sudah paham seluk beluk pekerjaannya, sehingga SR tidak terlalu banyak berpikir dalam bekerja, semua pekerjaan dikantor sudah dikuasai dan sudah dikerjakan secara rutin. Dampak WFH tidak begitu terasa, justru membuat keadaan semakin menyenangkan, karena selain bekerja dari rumah dengan pekerjaan yang sudah di kuasai, anak-anak sudah mandiri, SR dapat menjalankan hobi memasaknya yang kalau dulu sebelum WFH tidak sempat 
dilakukan, kecuali di hari sabtu dan minggu. Kini setiap hari bisa melakukan hobi masak dan membuat kue, bahkan sudah menerima orderan PO. Bekerja sesuai hobi membuat SR sangat bersemangat, sekaligus membangun jembatan untuk menghakhiri karier, sehingga dapat tetap produktif dan berpenghasilan setelah pensiun.

Informasi Partisipan 6, inisial KA. Pegawai Negeri Sipil. berusia 53 Tahun. Dimasa tahap akhir karier, sudah tidak memiliki keinginan atau ambisi untuk berprestasi. Di kantor KA hanya mengerjakan pekerjaan rutin, membantu menjadi mentor bagi teman atau rekan-rekan kerja. Fokus pikirannya saat ini adalah bagaimana caranya nanti untuk menghadapi dan menjalani masa pensiun dengan tenang. KA sudah tidak memiliki target dalam bekerja, tidak seperti dulu, malah dia lebih mendukung junior untuk maju dan berkembang. Dampak WFH justru membuat KA lebih senang, karena dapat melakukan hal-hal yg tidak pernah dilakukan sebelumnya, seperti berlatih yoga melalui aplikasi Youtube. Pekerjaan kantor berbentuk pertemuan rutin bisa dikerjakan di rumah melalui zoom meeting. Sakit pinggang yg biasanya diderita karena harus duduk 8 jam kerja dikantor, kini sudah tidak dirasakan, karena tetap dapat berolahraga yoga secara rutin di rumah saat jam istirahat. Pekerjaan kantor dapat dilakukan sambil mengawasi cucu yang sedang lucu-lucunya berumur 2,5 th dari anak pertamanya, ini merupakan kebahagiaan tak terkira yang KA rasakan semenjak $W F H$.

Berdasarkan hasil wawancara mendalam, kemudian dilanjutkan pemantapan kredibilitas data penelitian, yang dilakukan dengan member check, maka dapat ditarik pemaknaan dampak WFH pada model pengembangan karier wanita sebagai berikut. Pertama, perilaku work from home berdasarkan idealistic achievement model, terdiri dari wanita awal karier berusia 24 sampai 35 tahun, dimana keinginannya adalah mampu menghadapi pekerjaan yang menantang, semangat dalam bekerja dan berprestasi, sehingga dapat mengembaangkan kariernya ketingkat yang lebih tinggi.

Dampak WFH bagi wanita pada tahap awal karier dipandang sebagai hambatan dalam mencapai karier mereka. WFH mengakibatkan mereka tidak bisa fokus dalam bekerja di rumah, seringkali kehilangan ide yang sudah tersirat karena gangguan dari lingkungan sekitar terutama anak-anak yang masih kecil yang butuh perhatian. Hal ini membuat pekerjaan kantor yang dilakukan di rumah menjadi tidak maksimal, target tidak tercapai dan kinerja kerja menjadi turun. Sama halnya dengan karyawan wanita di Jerman, mereka lebih cenderung merasakan hambatan budaya untuk bekerja dari rumah, karena, mereka lebih cenderung merasakan ketidaksesuaian pekerjaan dengan bekerja dari rumah, banyak hal yang tidak bisa dilakukan dirumah karena hambatan domestik, dimana peran keluarga cenderung mendominasi ketika berada di rumah (Lott \& Abendroth, 2019). Dimensi yang berbeda dari pengalaman bekerja dari rumah menimbulkan ketakutan tersendiri bagi wanita,sehingga mereka tidakmampu bekerja sesuai target yang mempengaruhi harapan 
kariernya untuk masa depan (Couch et al., 2021)

Kedua, perilaku work from home berdasarkan pragmatic endurance model, terdiri dari wanita pertengahan karier berusia 36 sampai 45 tahun yang dianggap memiliki konteks relasional tinggi. Mereka pada tahap berupaya menyeimbangkan tanggung jawab profesional pada perusahaan dan tanggung jawab pribadi pada keluarga. Dalam bekerja tidak ingin terlihat menonjol, hal ini dimaksudkan agar mereka diberikan tanggung jawab pekerjaan yang lebih ringan, sehingga dapat membagi waktunya untuk keluarga.

Pada fase ini, WFH tidak terlalu berdampak pada wanita yang berada pada tahap pertengahan karier. Wanita karier disini justru merasa WFH membuat hidupnya lebih mudah untuk menjalani kedua perannya dengan seimbang, sebagai karyawan dan ibu rumah tangga. Mereka merasa menjalani pekerjaan tanpa beban karena tidak pernah lagi meninggalkan keluarga ke luar kota seperti sebelumnya dan semua pekerjaan dapat dilakukan di rumah sambil menjaga anak-anak dan keluarga. Senada dengan wanita pekerja di India, mereka melakukan perjalanan jarak jauh setiap hari untuk mencapai tempat kerja, dan kemampuan untuk bekerja dari rumah telah menghemat banyak waktu yang biasanya hilang dalam perjalanan, sehingga waktu tersebut lebih bermanfaat untuk menyeimbangkan peran yang lain (Bhattacharjee, 2020).

Ketiga, perilaku work from home berdasarkan re-inventive contribution model, terdiri dari wanita karier yang berusia 46 sampai 60 tahun, mereka lebih memilih untuk mengambil sikap aktif dalam membantu rekan sekerja yang lain untuk maju. Mereka melihat fase saat ini sebagai kesempatan berbagi ilmu dan berbuat kebaikan untuk orang lain, sehingga dalam sisa kariernya dapat memberi manfaat untuk sekitarnya. Tujuannya saat ini, hanya bekerja dengan baik tanpa beban, karena pekerjaan dikantor sudah dikuasai serta memikirkan jalan untuk memasuki usia pensiun dengan tenang.

WFH berdampak menyenangkan bagi wanita yang berada pada tahap akhir karier, mereka dapat bekerja di rumah sambil menjalankan hobi seperti memasak, membuat kue, berolahraga, yang tidak bisa mereka lakukan sebelum kebijakan WFH. Hobi ini selain meningkatkan kesehatan juga mampu membangun jembatan bagi mereka yang akan mengakhiri masa kerja atau pensiun. Hobi ini dapat menjadi sarana meningkatkan kesejahteraan lahir dan batin, sehingga mereka menjadi sehat, dan masih dapat produktif serta berpenghasilan di masa pensiun. Wanita pekerja pada siklus ini seringkali berada pada kondisi menopause, yang ditunjukkan dengan gejala psikologis seperti ingatan yang buruk, kemampuan yang kurang untuk berkonsentrasi atau membuat keputusan, perubahan suasana hati, ledakan emosi, lekas marah, depresi, dan kecemasan. Seringkali tempat kerja semakin memperburuk gejalanya, namun dengan bekerja dari rumah, mereka memiliki lingkungan kerjanya yang lebih tenang, mereka tidak akan melakukan interaksi fisik dengan manajer, kolega, atau klien/pelanggan sehingga terhindar dari rasa persaingan dan stress. Hal ini membuat perubahan suasana 
hati atau kekhawatiran tentang presentasi diri lebih mudah ditangani. Selain itu, bekerja dari rumah disini berarti setiap wanita dapat mengambil langkah-langkah yang diperlukan untuk membuat mereka lebih nyaman, misalnya memakai pakaian yang lebih nyaman saat bekerja. Bekerja dari rumah memungkinkan mereka untuk mengatur harinya sendiri dan bekerja lebih fleksibel secara umum (Brewis, 2020).

\section{SIMPULAN DAN SARAN}

Berdasarkan hasil pembahasan tersebut dapat disimpulkan bahwa dampak WFH pada model pengembangan karier wanita di setiap fase hidup wanita karier berbeda, yaitu; 1) Idealistic achievement model merupakan wanita tahap karier awal yang berkeinginan untuk berprestasi untuk meningkatkan jenjang kariernya, namun WFH berdampak tidak baik bagi mereka karena dianggap sebagai penghambat dalam melaksanakan pekerjaan sehingga akan berpotensi menurunkan kinerja kariernya. 2) Pragmatic endurance model merupakan wanita tahap pertengahan karier yang berada pada profesional pekerjaan dan keluarga, sehingga mereka menjauh dari prestasi dan lebih berhati-hati, namun tetap bekerja dengan baik. Mereka merasa WFH merupakan jawaban atas keterbatasan mereka selama ini dalam menyeimbangkan kedua perannya sebagai karyawan dan ibu rumah tangga. 3) Re-inventive contribution model merupakan wanita pada tahap karier akhir, mereka tidak berfikir tentang prestasi lagi, namun memandang karier mereka sebagai kesempatan untuk berbagi dan bermanfaat bagi orang sekitar. Mereka sangat mendukung WFH karena mampu meningkatkan kesejahteraan lahir batin menjelang menghadapi masa pensiun. Mereka dapat menjalankan hobi sambil bekerja, sehingga merasa menjadi lebih sehat, tetap produktif dan berpenghasilan untuk mempersiapkan masa akhir karier menuju pensiun.

Penelitian ini hanya difokuskan bagi wanita dengan dua peran yakni keluarga dan pekerjaan, oleh karena itu untuk penelitian selanjutnya akan menarik jika kriteria partisipan yang dipilih memiliki lebih banyak peran, sehingga model pengembangan karier wanita yang dihasilkan akan lebih komprehensif.

Berdasarkan hasil penelitian yang telah dilakukan maka dapat diberikan saran kepada pihak manajemen perusahaan, yang sekiranya dapat membantu untuk meningkatkan kinerja wanita karier, yaitu: 1) Memperhatikan karyawan wanita dengan membagi mereka kedalam tiga tahapan karier, yakni; fase/tahap karier awal, pertengahan atau akhir. 2) Dalam menentukan kebijakan WFH sebaiknya memperhatikan pembagian tahapan karier tersebut dimana, sebaiknya wanita pada tahap awal karier diberikan shift bekerja dikantor lebih banyak dibandingkan karyawan wanita yang berada pada fase pertengahan dan akhir karier. Karena apabila mereka bekerja dengan hati yang senang, nyaman akan mampu meningkatkan kinerja kerja, yang pada gilirannya akan meningkatkan kinerja perusahaan secara keseluruhan. 


\section{REFERENSI}

Banerjee, G., \& Pati, I. (2020). Women working from home during COVID-19: An Analysis. Parikalpana: KIIT Journal of Management, 16(1\&2), 173-191. https://doi.org/10.23862/ kiit-parikalpana/2020/v16/i1-2/204566

Bhattacharjee, S. (2020). 'Work from home' as an alternative to daily commuting for working women. Human Geographies, 14(2), 255-265. https://doi.org/10.5719/hgeo.2020.142.5

Brewis, J. (2020). The health and socioeconomic impact on menopausal women of working from home. Case Reports in Women's Health 27(1)1-6. https://doi.org/10.1016/j.crwh.2020. e00229

Couch, D. L., O’Sullivan, B., \& Malatzky, C. (2021). What COVID-19 could mean for the future of "work from home": The provocations of three women in the academy. Gender, Work and Organization, 28(S1), 266-275. https://doi.org/10.1111/gwao.12548

Elfira, M., Wibawarta, B., Esther, R., \& Febriand, F. (2021). Working From Home: Women Between Public And Domestic Spheres After The Outbreak Of Covid-19. International Review of Humanities Studies, 6(1), 375-389. https://doi.org/10.7454/irhs.v6i1.326

Kaur, T., \& Sharma, P. (2020). A Study on Working Women and Work from Home Amid Coronavirus Pandemic. Journal of Xi'an University of Architecture \& Technology, Parikalpana KIIT Jurnal of Management, 16(1\&2), 5-11. https://doi.org/10.23862/kiitparikalpana/2020/v16/i1-2/204561

Komalasari, Y., Supartha, W. G., Rahyuda, A. G., \& Dewi, I. G. A. M. (2017). Fear of Success on Women's Career Development: A Research and Future Agenda. European Journal of International Management 9(11), 60-65.

Komalasari, Y. (2020). Perilaku Orientasi Kesuksesan Karier Berdasarkan Women's Career Development Models (Studi Pada Wanita Karier Kota Denpasar Bali). E-Jurnal Ekonomi Dan Bisnis Universitas Udayana. 9(5), 423-434. https://doi.org/10.24843/eeb. 2020.v09.i05.p03

Kumar, S. (2020). Corona Virus Outbreak: Keep Physical Distancing, Not Social Distancing. SSRN Electronic Journal. 6(1)1-10. https://doi.org/10.2139/ssrn.3568435

Lott, Y., \& Abendroth, A. (2019). Reasons for Not Working From Home in an Ideal Worker
Culture: Why Women Perceive More Cultural Barriers. WSI Working Paper, No.211, 1-31.

Moleong, L. J. (2019). Metodologi Penelitian Kualitatif Edisi Revisi. Bandung :Remaja Rosdakarya.

O’Neil, D. A., \& Bilimoria, D. (2005a). Women's career development phases: Idealism, endurance, and reinvention. Career Development International, 10(3), 168-189. https://doi.org/10.1108/13620430510598300

Pfattheicher, S., Nockur, L., Böhm, R., Sassenrath, C., \& Petersen, M. B. (2020). The Emotional Path to Action: Empathy Promotes Physical Distancing and Wearing of Face Masks During the COVID-19 Pandemic. Psychological Science, 31(11), 1363-1373. https://doi.org/10.1177/0956797620964422

Prem, K., Liu, Y., Russell, T. W., Kucharski, A. J., Eggo, R. M., Davies, N., Flasche, S., Clifford, S., Pearson, C. A. B., Munday, J. D., Abbott, S., Gibbs, H., Rosello, A., Quilty, B. J., Jombart, T., Sun, F., Diamond, C., Gimma, A., van Zandvoort, K., ... Klepac, P. (2020). The effect of control strategies to reduce social mixing on outcomes of the COVID-19 epidemic in Wuhan, China: a modelling study. The Lancet Public Health, 5(5), 261-270. https://doi.org/10.1016/S2468-2667(20)300 73-6

Raju, S., \& Kumar, V. K. (2020). Quality of life of women working from home in COVID-19 lockdown: a questionnaire survey. International Journal of Community Medicine And Public Health, 7(10), 39-47. https://doi.org/10.18203/2394-6040.ijcmph 20204359

Rupietta, K., \& Beckmann, M. (2018). Working from Home. Schmalenbach Bus Rev 70, 25-55 https://doi.org/10.1007/s41464-017-0043-X

Smith, J. A., \& Osborn, M. (2008). Interpretative Phenomenological Analysis. In Doing Social Psychology Research, 5(5), 53-80. https://doi.org/10.1002/9780470776278.ch10

van der Lippe, T., \& Lippényi, Z. (2020). Beyond Formal Access: Organizational Context, Working From Home, and Work-Family Conflict of Men and Women in European Workplaces. Social Indicators Research, 151(2), 383-402. https://doi.org/10.1007/s112 05-018-1993-1 
Harmonisasi Work From Home Pada... Yeyen Komalasari

Poerwandari.E.K. (2011). Pendekatan Kualitatif dalam Penelitian Psikologi. Jakarta: LPSP3 Psikologi UI.

Sugiyono. (2016). Statistika Untuk Penelitian. Bandung: Alfabeta. 